\title{
Intercropping of African marigold (Tagetes erecta Linnaeus (Asteraceae)) Varieties at Different Plant Density with Tomato (Solanum iycopersicum Linnaeus (Solanaceae)) on Yield Related Traits and Yield of tomato at Wondo Genet, Southern Ethiopia
}

\author{
Wondimkun Dikr*1 Ketema Belete ${ }^{2}$ \\ 1. Ethiopian Institute of Agricultural Research, Wondo Genet Agricultural Research Center \\ 2.Haramaya University College of Agriculture and Environmental Science School of plant science Agronomy \\ department \\ Corresponding Author: P.O Box, 198 Shashemene, Ethiopia
}

\begin{abstract}
Tomato is among the most important vegetable crops in Ethiopia. Planting marigolds between tomatoes protects the tomato plants from harmful root-knot nematodes in the soil and increase the marketable fruit yield of tomato by trapping different insects and pest attack and the like. Field experiment was conducted to assess effect of plant densities of intercropped African Marigold Varieties on yield related traits and yield of tomato and to evaluate the productivity and economic value of tomato and African marigold intercropping system, in southern parts of Ethiopia, at Wondo Genet Agricultural Research Center in 2017/18 cropping season. Three varieties of African marigold (AVT 001, AVT 540 and AVT 7063) at three population densities (PD) $(25 \%, 50 \%$, and $75 \%$ ) were intercropped with tomato variety 'Melkashola'. The three varieties of African marigold (AFM) and tomato were included as a sole for comparison. Randomized complete block design in factorial with three replications was used. Plant height, days to $50 \%$ flowering, days to physiological maturity and days to first harvest of tomato were not significantly affected by varieties of African marigold, population densities, interaction and cropping system. Harvest duration of tomato was delayed (27.56 days) and hastened (25.78 days) by variety AVT 540 and AVT 001 , respectively as compared to VAT 7063. The highest (7.56) number of primary branches was due to $50 \% \mathrm{PD}$ African marigold (AFM). The 50\% PD delayed harvest duration (29.56 days) as compared to other PD. The highest number of harvest (3.91), numbers of fruit per plant (45.89) and number of fruit per cluster (15.56) were also obtained due to $50 \% \mathrm{PD}$. The highest fruit weight $\left(13.80\right.$ ton ha $\left.^{-1}\right)$ and marketable fruit yield $\left(13.11\right.$ ton ha $\left.{ }^{-1}\right)$ were also obtained from $50 \%$ PD, but the highest unmarketable fruit yield $\left(3.24\right.$ ton ha $\left.{ }^{-1}\right)$ was obtained from $25 \%$. Cropping system was showed non-significant effect except marketable and unmarketable fruit yield of tomato, the highest marketable (10.19 ton ha $\left.\mathrm{a}^{-1}\right)$ and unmarketable $\left(4.37\right.$ ton ha $\left.^{-1}\right)$ fruit yield were obtained from intercropped and sole cropping of tomato respectively. The highest (0.84) partial land equivalent ratio (LER) of tomato and total LER (1.43) were due to 50\% PD. The highest value of monetary advantage index $\left(37,225 \mathrm{ETB} \mathrm{ha}^{-1}\right)$ was due to $50 \%$ PD. Therefore, any of the three African marigold varieties at $50 \%$ PD could be recommended for intercropping with tomato.
\end{abstract}

Keywords: Cropping system, Marketable fruit yield, Population density and Unmarketable fruit yield.

DOI: $10.7176 / \mathrm{JBAH} / 11-6-01$

Publication date:March $31^{\text {st }} 2021$

\section{INTRODUCTION}

Tomato (Solanum iycoperisicum Linnaeus (Solanaceae) is one of the most widely grown vegetable crops in the world, next to potato. It originally came from tropical area from Mexico to Peru (Mazaher et al., 2006; FAO, 2015). Its use as a food originated in Mexico and spread throughout the world following the Spanish colonization of the Americas (Cox, 2000). Tomato originated in the Andes mountain region of South America. Early domestication was undertaken by the Native Americans. The first encounter with tomato by Europeans appears to be during a voyage by Cortez in 1519, when he acquired some tomato plants in Mexico (Cox, 2000). The tomato was distributed throughout Europe in the years following. The tomato was actually taken by the Moors first through Spain, and then more widely distributed. The Moors' involvement resulted in one of the first European names for tomato (Moor's apple). However in Ethiopia, there is no exact information as to when tomato was first introduced; but, the crop is cultivated in different major growing areas of the country. In 1966 tomato was recognized as a commodity crop by Ethiopian Institute of Agricultural Research (EIAR) (Setotaw, 2006). The first record of commercial tomato cultivation is from 1980 with a production area of 80 ha in the upper Awash by Merti Agroindustry for both domestic as well as export markets (Lemma, 2002). The total area increased to 833 hectare by the year 1993 and later-on the cultivation spread towards other parts of the country. In Ethiopia, tomato ranks fifth in total production (3.76\%) after Ethiopian cabbage, red peppers, green peppers and head cabbage; is also fifth in area coverage $(2.51 \%)$ next to red peppers, Ethiopian cabbage, green peppers and Head cabbage from vegetable crops cultivated (CSA, 2018). Its national mean yield is 5.3 ton/ha (CSA, 2018). In 2017/18 Ethiopian Meher (rain 
fed) cropping season tomato production was estimated with an area of 5,235.19 ha and a total production of 27,774.5 tons (CSA, 2018). The off season production is estimated to be higher than the Meher season.

Tomato is among the most important vegetable crops in Ethiopia. Both fresh and processed tomato varieties are popular and economically important vegetable crops produced in the country (Geleta et al., 1995). The total production of this crop in the country has shown a marked increase since it became the most profitable crop providing a higher income to small scale farmers compared to other vegetable crops (Lemma et al., 2003). It is used as canned vegetable having multiple uses and supplies an essential nutrient in human diets (Choudhury, 1979). It is mainly used for both commercial and home use purposes. The fresh produce is sliced and used as salad. It is also cooked for making local saucer ('watt'). The processed products like tomato paste, tomato juice, tomato catchup and whole peel-tomato are produced in the country for local market and export. It was recognized as quality product for both local and export markets and providing a route out of poverty for small scale producers who live in developing countries in general and in Ethiopia in particular (Tewodros and Asfaw, 2013).

Tomato is one the most widely cultivated vegetable crops in our country and specifically around Wondo Genet area. Intercropping of African marigold within the row of tomato is the best way of introducing and increasing the production and productivity of African marigold in Ethiopia. Tomato was the main crop because it is mainly cultivated from vegetable crop around Wondo Genet area but, African marigold was the companion crop.

Marigold (Tagetes erecta Linnaeus (Asteraceae) is aromatic medicinal crop native of central and South America especially Mexico and belongs to the family Asteraceae (Compositae). There are 33 species of genus Tagetes. However the cultivated types of marigold are African marigold and French marigold (NHB 2013-14).

Members of the genus Tagetes have a long history of human use as beverages, condiments, ornamentals, and medicinal purpose such as analgesics, antiseptics, carminative, diuretic, antispasmodic, anthelmintic, stimulants, vermin repellents, and for treatment of stomach and intestinal diseases (Singh et al., 2006). Tagetes minuta L., commonly known as African marigold, is a highly aromatic annual perennial herb growing. It is cultivated for 'Tagetes oil' (Singh et al., 2016).

Marigold and tomato companion planting is a tested and true technique used by gardeners for hundreds of years. Research studies have indicated that planting marigolds between tomatoes protects the tomato plants from harmful root-knot nematodes in the soil. Although scientists tend to be skeptical, many gardeners are convinced that the pungent scent of marigolds also discourages a variety of pests such tomato hornworms, whiteflies, thrips, and maybe even rabbits. Allow 45 to $60 \mathrm{~cm}$ between the marigold and the tomato plant, which is close enough for the marigold to benefit the tomato, but allows plenty of space for the tomato grow (https://www.gardeningknowhow.com/ornamental/flowers/marigold/marigoldtomatocomanio ns.htm).

Marigold repels nematodes, tomato worm, slugs and general garden pests. Gomez Rodriguez et al. (2003) found that intercropping of tomato with African marigold (T.erecta) reduced early blight (Alternaria solani Sorauer,(Pleosporales: Pleosporaceae))) of tomato in three ways: (1) allelopathic effect on A.solani development, (2) reduced humidity levels below those conducive to the pathogen requirement, and (3) behaved as a physical barrier against spore dispersal (Gómez Rodriguez et al., 2003; Zavaleta-Mejía and Gómez, 1995). Intercropping marigold for nematode management also appeared to reduce numbers of aphids and whiteflies, and resulted in lower levels of virus in tomato (Zavaleta-Mejía and Gómez, 1995).

There is a lack of information about the intercropping system and related planting density of African marigold with that of the component crops, due to recent information to the country and lack of awareness for the people about the economic importance of African marigold in Ethiopia. The importance of this crop was understood by WGARC and it was introduced to Ethiopia from Indian through Av Tomas (AVT) Natural Products PLC Company and the adaptations of the three African marigold varieties (AVT 001, AVT 540 and AVT 7063) were tested and registered.

Tomato is one of the high demanded vegetable crops by the growers. In the past, growth in food production was achieved by using more land but, more recently, the increase in productivity per unit area is the concern. Intercropping of tomato with African marigold is one of the methods of achieving high yield per unit area and harvesting more than one crop per season from a piece of land. Intercropping is receiving attention because it offers potential advantages for resource utilization, decreased inputs and increased sustainability in crop production, but our understanding of interactions and planting density among the intercropped species (like, tomato and African marigold) is still very limited (Egbe, 2010). Intercropping might positively impact on the future food problems in developing countries (Egbe, 2005). Also, optimization of land resource could be achieved when crops are grown under intercropping and plant population density increased.

The common goals of intercropping vegetable with other crops are to produce greater yield on a given piece of land, making use of resources that would otherwise not be utilized by a single crop. Since African marigold is recently introduced to the country, the farmers are reluctant to produce this crop as sole crop. Thus is a need of indentifying different crops such as African marigold (T.erecta L.) to be intercropped with tomato.

Therefore, the general objective of this study is:

* to determine the tomato-African marigold intercropping. 
The specific objectives of this study are:

* to assess effect of plant densities of intercropped African marigold varieties on yield related traits and yield of tomato; and

* to evaluate the productivity and economic value of tomato and African marigold intercropping system

\section{MATERIALS AND METHODS}

\section{Description of the Study Area}

The study was conducted at the experimental field of Wondo Genet Agricultural Research Center (WGARC) during the 2017/18 off cropping season (through irrigation) from end of October 2017 to mid of January 2018. Wondo Genet is located in South Nation Nationality and People's Regional State which is 274 km away from Addis Ababa. The geographical coordinate of the research site is $7^{\circ} 19^{\prime} \mathrm{N}$ and $38^{\circ} 38^{\prime} \mathrm{E}$ with an altitude of 1780 meters above sea level. The mean annual rainfall is $1390 \mathrm{~mm}$. The site has mean maximum and minimum temperatures of $26^{\circ} \mathrm{C}$ and $12^{\circ} \mathrm{C}$, respectively. Wondo Genet has a bimodal rainfall distribution with two rainy seasons. Short rains occur during March to May and the long rains occur from July to October. The dry season extends from November to February (Dawit and Afework, 2008). The soil type of the experimental area is Nitosols and it has a textural class of sandy clay loam with $\mathrm{pH}$ of 6.4 (Abayneh et al., 2006). The center mainly has a national mandate to conduct researches on medicinal and aromatic plants (MAPs).

\section{Description of the Experimental Materials}

Tomato: the available determinate improved type of tomatoes' variety 'Melkashola' was used. It was released by Melkassa Agricultural Research Center and adapted to altitude of 1000 to 1800 meter above sea level and matures in 144 days. It requires $1000 \mathrm{~mm}$ to $1200 \mathrm{~mm}$ annual rainfall and the potential yield of variety was 8-9.5-ton ha-1 at research and 5.5-6.5-ton ha $^{-1}$ at farmer's field (Lemma, 2003).

African marigold: Three African marigold varieties namely AVT001, AVT540 and AVT7063 which were introduced from India through AVT Natural Products Plc to WGARC were used. It was first introduced to Ethiopia from Indian through Av Tomas (AVT) Natural Products PLc Company and the adaptations of the three African marigold varieties (AVT 001, AVT 540 and AVT 7063) were tested and registered. The varieties were well adapted and two of them gave better yield than in India (Beemnet, 2015).

\section{Treatments and Experimental Design}

The experiment was consisting of two factors, the three African marigold varieties (AVT 001, AVT 540 and AVT

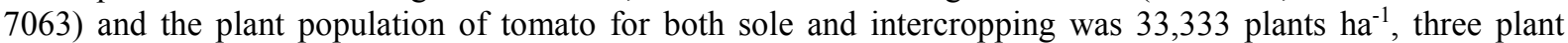
densities of African marigold (T. erecta) 25\% (20,833.333 plants ha $\left.{ }^{-1}\right), 50 \%\left(41,666.67\right.$ plants ha $\left.{ }^{-1}\right)$ and $75 \%$ $\left(62,500\right.$ plants $\left.\mathrm{ha}^{-1}\right)$ and the sole planting of marigold was $83,333.333 \mathrm{ha}^{-1}$.

Table 1. Description of the Treatments

\begin{tabular}{clllll}
\hline \multirow{2}{*}{ Trts. } & A.mariglod spacing & $\begin{array}{l}\text { Varieties of } \\
\text { A.mariglod }\end{array}$ & $\begin{array}{l}\text { A. marigold } \\
\text { PD/ha }\end{array}$ & Remark \\
\cline { 2 - 4 } & $\begin{array}{l}\text { Intra-row } \\
\text { spacing }(\mathrm{cm})\end{array}$ & $\begin{array}{l}\text { Inter-row } \\
\text { spacing(cm) }\end{array}$ & & \\
\hline 1 & 96 & 50 & AVT 001 & $20,833.333$ & $25 \%$ of AVT 001 \\
2 & 48 & 50 & AVT 001 & $41,666.67$ & $50 \%$ of AVT 001 \\
3 & 32 & 50 & AVT 001 & 62500 & $75 \%$ of AVT 001 \\
4 & 96 & 50 & AVT 540 & $20,833.333$ & $25 \%$ of AVT 540 \\
5 & 48 & 50 & AVT 540 & $41,666.67$ & $50 \%$ of AVT 540 \\
6 & 32 & 50 & AVT 540 & 62500 & $75 \%$ of AVT 540 \\
7 & 96 & 50 & AVT 7063 & $20,833.333$ & $25 \%$ of AVT 7063 \\
8 & 48 & 50 & AVT 7063 & $41,666.67$ & $50 \%$ of AVT 7063 \\
9 & 32 & 50 & AVT 7063 & 62500 & $75 \%$ of AVT 7063 \\
10 & 30 & 100 & Melkashola & $33,333.333$ & Sole tomato \\
11 & 30 & 40 & AVT 001 & $83,333.333$ & Sole AVT 001 \\
12 & 30 & 40 & AVT 540 & $83,333.333$ & Sole AVT 540 \\
13 & 30 & 40 & AVT 7063 & $83,333.333$ & Sole AVT 7063 \\
\hline
\end{tabular}

Where $100 \%$ population density throughout the treatments, Trts = treatments, $\mathrm{PD}=$ population density, A. marigold $=$ African marigold .

Randomized complete block design with three replications in factorial arrangement was used. The detail of treatment is given in Table 1. The marigold was planted between the two tomato rows. Uniform populations of 33,333 plants ha ${ }^{-1}$ was also maintained for tomatoes in both intercropping and sole cropping. 


\section{Experimental Procedures and Field Management}

Seedling preparation, planting and management

The seedling of tomato variety 'Melkashola' was raised in nursery. Healthy and uniform seedlings with 3 to 4 leaf number were transplanted at the age of 30 days after sowing. The seedlings were irrigated after transplanting. Seedlings of African marigold varieties were raised in the nursery for 45 days until they are about $20 \mathrm{~cm}$ in length and then transplanted to the main experimental filed. Marigold seedlings are easily transplanted and established in the main field without much mortality. The sole African marigold seedlings were transplanted to the main field with a spacing of $30 \mathrm{~cm} \mathrm{x} 40 \mathrm{~cm}$.

\section{Land preparation, field layout and transplanting}

Both tomato and African marigold varieties were sown on nursery at the start September and October, respectively and transplanted to the main field at the end of October and middle of November, 2017 respectively.

The experimental field was ploughed and harrowed by a tractor to get a fine field. It was leveled by manually before the field layout was made. The distance between plot and block was $1 \mathrm{~m}$ and $1.5 \mathrm{~m}$ respectively. The sole and intercropped tomato consisted of six rows, while sole and intercrop African marigold consisted of twelve and five rows, respectively. Inter-row spacing of $100 \mathrm{~cm}$ and with the intra- row spacing of $30 \mathrm{~cm}$ was used for both sole and intercropped tomato. The inter-row and intra- row spacing for sole African marigold was $40 \mathrm{~cm}$ and 30 $\mathrm{cm}$ respectively. The row length of the experiment was $1.8 \mathrm{~m}$; therefore the gross plot of was also $10.8 \mathrm{~m}^{2}(1.8 \mathrm{~m}$ x $6 \mathrm{~m})$. The net plot area for sole and intercrop tomato was $7.5 \mathrm{~m}^{2}(1.5 \mathrm{~m} \mathrm{x} 5 \mathrm{~m})$. This experiment field had a total area of $41.4 \mathrm{~m} \mathrm{x} 21 \mathrm{~m}\left(869.4 \mathrm{~m}^{2}\right)$. The data was taken from the central rows for tomato by taking the five randomly taken plants while in data collection. The African marigold were intercropped between two rows of tomato at 50 $\mathrm{cm}$ away from tomato row with intra-row $32 \mathrm{~cm}, 48 \mathrm{~cm}$ and $96 \mathrm{~cm}$ for $75 \%, 50 \%$ and $25 \%$ population density of the recommended sole population density, respectively. The sole population density of $83,333.333$ plants ha $^{-1}$ African marigold was used. Uniform populations of 33,333 plants $\mathrm{ha}^{-1}$ was maintained for sole and intercropped tomato. At the time of transplanting, seedling of African marigold should be stocky and bear 3-5 true leaves. Thin and long seedlings do not make a good plant. Very old seedlings are also not desirable and seedling of 4 and 5 weeks old for tomato and African marigold were transplanted, respectively.

\section{Fertilizer application rates and other agronomic practices}

Inorganic fertilizers, urea (in the form of N) and DAP fertilizer were applied at the rate of $100 \mathrm{~kg} \mathrm{ha}^{-1} \mathrm{and}^{9} \mathrm{kgh}^{-}$ ${ }^{1}$, respectively on tomato (Edossa et al., 2013). The whole amount of DAP fertilizer was applied at the time of transplanting, whereas half rate of urea applied after well established and the remaining half was applied at vegetative stage of the plant. The component crops were irrigated once in a week through furrowing.

\section{Harvesting of fruits}

Marigold flowers started to flower from 40-50 days and plucked when they have attained full size. Plucking of flowers was done in cool hours of the day. The fruit of tomato was also harvested after 3 months.

\section{Data Collection and Measurements \\ Tomato phenology, growth, yield component and yield \\ Phenological characters}

Days to $\mathbf{5 0} \%$ flowering: recorded when $50 \%$ plants flowered in a plots starting from the date of transplanting.

Days to physiological maturity: calculated as the number of days when $90 \%$ the plant in plot attained its maturity.

\section{Growth parameters}

Plant height (cm): measured at $90 \%$ physiological maturity from the soil surface to tips of the plant from 5 randomly taken plants.

Number of primary branches per plant: the number of primary emerging from the main stem was counted at $90 \%$ physiological maturity from 5 randomly taken plants.

Days to first harvest: counted as the number of days elapsed from the date of transplanting to first harvesting. Harvest duration (days): calculated as number of days from the date of first harvest to last harvesting dates. Number of harvesting: the number of harvest from first to last picking and recorded.

\section{Yield components and yields}

Fruit cluster per plant: the number of fruit cluster of 5 randomly taken plants and the average was noted. Number of fruits per plant: the number of fruits from 5 randomly taken plants and the average fruit number were noted.

Total fruit yield (ton ha-1): the weight of an individual tomato fruit was calculated by dividing the number of fruits counted from 5 randomly taken plants, it converted in to ton per hectare (ton ha $\mathrm{h}^{-1}$ ). It includes both 
marketable and unmarketable fruit yield of tomato.

Marketable fruit yield of tomato (ton $\left.\mathbf{h a}^{-1}\right)$ : Fruits of tomato free from damages, disease and defects were weighted (ton ha-1) at each harvest from total fruit yield as marketable yields and converted into ton ha' ${ }^{-1}$.

Unmarketable fruit yield of tomato (ton $\mathbf{h a}^{-1}$ ): fruits with cracks, damaged by insects, diseases, birds, sunscald and blossom-end-rot...etc were considered at each harvest as unmarketable fruits and calculated $\mathrm{kg} \mathrm{plot}^{-1}$ and converted to ton $\mathrm{ha}^{-1}$. Unmarketable yield was calculated in percent, to know how much of it was not profitable or not had been sold, as follows: $\mathrm{UY}=(\mathrm{UY} / \mathrm{TY}) \times 100 \%$ Where, $\mathrm{UY}$ is unmarketable yield and TY is total yield. Total fruit yield of tomato $(\mathrm{t} / \mathrm{ha})$ : the fruit yield obtained at each harvest from the central rows was used for this parameter. It was also recorded at the time of each harvest then all the harvested fruit yield was summed and converted to ton $\mathrm{ha}^{-1}$.

\section{System productivity}

\section{Land equivalent ratio (LER)}

Partial land equivalent ratio: is the ration of intercropped and sole cropped yield of the individual crop. For instance the partial land equivalent ratio of tomato was calculated as,

Partial LER of tomato $=\frac{\text { YTi }}{\mathrm{YTs}}$; where $\mathrm{YTi}=$ intercropped yield of tomato and $\mathrm{YTs}=$ fruit yield of sole cropped tomato. Similar to tomato the partial land equivalent ratio of African marigold was also calculated as; partial land equivalent ratio of African marigold $=\frac{\text { YAFMi }}{\text { YAFMS }} \quad$ where YAFMi $=$ intercropped yield of African marigold and YAFMs = sole cropped of African marigold.

The LER was calculated using the formula $\mathrm{LER}=\Sigma(\mathrm{Ypi} / \mathrm{Ymi}$ ) (where Ypi is the yield of each crop in the intercrop, and $\mathrm{Yms}$ is the yield of each crop in the sole crop.

So in this study the LER was calculated as,

$\mathrm{LER}=\underline{\mathrm{YTi}}+\underline{\mathrm{YAmi}}$

YTs YAms (from the sole crop the actual yield was used from the three varieties)

\section{Where}

YTi $=$ Yield per unit area of tomato intercrop (net plot area of intercropped tomato)

YTs $=$ Yield per unit area of tomato sole (net plot area of sole tomato)

YAmi $=$ Yield per unit area of AFM in intercropping (net plot area of intercropped AFM)

YAms $=$ Yield per unit area of African marigold sole (net plot area of sole AFM)

\section{Monetary Advantage Index (MAI)}

First the Gross monetary value (GMV) was calculated as; Yield of component crops $\times$ respective market price; .i.e., (yield of tomato x price of tomato + yield of African marigold x price of African marigold) (Willey (1979).

In order to access the economic advantage of intercropping as compared to sole cropping of tomato and African marigold varieties, the gross monetary value (GMV) and the Monetary Advantage index (MAI) were calculated from the yield of tomato and African marigold $\left(\mathrm{kg} \mathrm{ha}^{-1}\right)$. Gross monetary value and monetary advantages were calculated to measure the productivity and profitability of the intercropping as compared to sole cropping of the component crops.

Monetary Advantage Index (MAI): The most important part of recommending a cropping pattern was the cost: benefit ratio more specifically total profit, because farmers are mostly interested in the monetary value of return. The yield of all the crops in different intercropping systems and also in sole cropping system and their economic return in terms of monetary value were evaluated to find out whether tomato fruit yield and additional African marigold yield were profitable or not. This is calculated with monetary advantage index (MAI) which indicates more profitability of the cropping system with the higher the index value (Mahapatra, 2011). It was expressed as $\mathrm{MAI}=(\mathrm{Pab}+\mathrm{Pba}) *(\mathrm{LER}-1) / \mathrm{LER}$ Where, $\mathrm{Pab}=\mathrm{Pa} \times \mathrm{Yab} ; \mathrm{Pba}=\mathrm{Pb} \times \mathrm{Yba} ; \mathrm{Pa}=$ Price of tomato and $\mathrm{Pb}=\mathrm{Price}$ of African marigold. In this research we used the price of African marigold 30 Ethiopian birr per kilo gram of dry flower yield. It was determined by socio-economic and agricultural extension research process in Wondo Genet Agricultural Research Center. This price was calculated based on the inputs (fertilizers, labor, transportation cost and others) used while doing this research activity because, the flower yield of African marigold is not determined in our marketing system, but the price of tomato was just taken from the local market. The price of tomato was fluctuated and seasonal but we used the average of maximum and minimum price of tomato fruit twelve Ethiopian birr per kilogram (ETB $\left.12 \mathrm{~kg}^{-1}\right)$.

\section{Statistical Data Analysis}

All data were subjected to the analysis of variance (ANOVA) appropriate to the randomized complete block design using SAS (SAS, 2002). Least significant difference (LSD) test at 5\% level of probability was also used for mean separation as procedure described by Gomez and Gomez, (1984). I used the linear model of RCBD while analyzed the data by SAS, Yijk = $+\mathrm{i}+\mathrm{j}+\mathrm{k}+\mathrm{ik}+\mathrm{ijk}$. Where, Yijk = the value of the response variable; 
= Common mean effect; $\quad \mathrm{i}=$ Effect of Population density; $\mathrm{j}=$ Effect of block; $\mathrm{k}=$ Effect of varieties; $\mathrm{ik}=$ Interaction effect of population density \& varieties; and $\mathrm{ijk}=$ Experiment error. For cropping system $Y i j=+i+j+k+i j$, where $Y i j=$ the value of the response variable; Common mean effect; $i=$ Effect of intercropped; $j=$ Effect of block and $k=$ Effect of sole cropping.

\section{RESULTS AND DISSCUSION}

Phenological and growth response of Tomato

Days to $50 \%$ flowering and days to physiological maturity of tomato

The analysis of variance showed that days to $50 \%$ flowering and days to physiological maturity of tomato were not significantly affected by varieties, there population density and interaction effect (Appendix Table 1). The result agreed with Ijoyah et al. (2015) who reported that population densities of okra did not significantly affected days to attain $50 \%$ flowering for okra in okra-egusi melon intercropping. Cropping system is not significantly affected days to $50 \%$ flowering and days to physiological maturity of tomato.

In contrast with this result Ijoyah (2012) who reported that the longer days to attain $50 \%$ flowering took more time for intercropped egusi melon in an egusi melon-maize intercrop as compared to sole egusi melon. The report of Hailu et al. (2015) disagreed with this result cropping system was significantly affected the days of $50 \%$ flowering and physiological maturity of tomato in intercropping of tomato with maize taken shortest time to reach physiological maturity than sole cropping. The findings of Abraha (2013) disagree with this result, revealed that in maize cowpea intercropping system the days of 50\% flowering of cowpea was earlier in sole cropping than from cowpea-maize intercropping.

\section{Plant height}

The effects of varieties of African marigold, population densities, their interaction effect and cropping system were not significant effect on plant height (Table 2. and Appendix Table.1). The experimental result of Bilasvar and Salmasi (2016) demonstrated there was no significant difference in plant height between different population densities and between cultivars of sweet basil.

\section{Number of primary branches}

Population density had a highly significance $(\mathrm{P}<0.01)$ effect on primary branches number. There was no significance effect due to variety, interaction effect of population density and varieties of African marigold and cropping system (Appendix Table 1).

The highest (7.56) and lowest (5.31) number of primary branches was due to $50 \%$ and $25 \%$ population density respectively (Table 2). Intercropping of African marigold at $50 \%$ planting density gave the highest numbers of primary branches because of the interspecies competition at $50 \%$ which enables to use natural resources effectively like sun light, fertilizer, nutrients and soil moisture. The net assimilation rate at $50 \%$ plant population density might be higher and more biomass might be also produced. This study is similar to Hailu et al. (2015) and Hussain (2003) on maize-tomato intercropping at 50\% population density gave the highest number of primary branches as compared to others, but Khorshidi et al. (2009) study showed that highest number of main branches per plant was recorded in lowest population density, while lowest number of main branches per plant was recorded in medium population density.

\section{Days to first harvest}

Population densities, varieties of African marigold, their interaction and cropping system had no significance effect on tomato (Appendix Table 2).

\section{Harvest duration of tomato}

Variety and population density showed significant $(\mathrm{P} \leq 0.05)$ effect and highly significant $(\mathrm{P}<0.01)$ effect on harvest duration, respectively; while the effect of interaction and cropping system were not significant (Appendix Table 2).

The $50 \%$ population density significantly delayed (29.56) harvesting and the $75 \%$ population density hastened (25.11) (Table 3). This indicates that 50\% population density gave more (extended) duration than population density as high as $75 \%$ and as low as $25 \%$ population. Variety AVT 001 was harvested earlier than the other two varieties. This variety might be more competent for light and other resources than the other two varieties. 
Table 2. Mean effects of population density, varieties, cropping system and their interaction on plant height, primary branch number and days of first harvest of tomato

\begin{tabular}{|c|c|c|c|}
\hline Population densities & $\begin{array}{l}\text { Plant height } \\
\text { (cm) }\end{array}$ & $\begin{array}{l}\text { Number of primary } \\
\text { branches per plant }\end{array}$ & $\begin{array}{l}\text { Days to first } \\
\text { harvest (days) }\end{array}$ \\
\hline $75 \%$ & 60.89 & $5.67 \mathrm{~b}$ & 93.24 \\
\hline $50 \%$ & 65.00 & $7.56 \mathrm{a}$ & 95.06 \\
\hline $25 \%$ & 61.56 & $5.31 \mathrm{~b}$ & 91.60 \\
\hline LSD (0.05) & NS & 0.81 & NS \\
\hline Varieties & & & \\
\hline AVT 001 & 66.44 & 6.20 & 95.46 \\
\hline AVT 540 & 62.00 & 6.19 & 93.08 \\
\hline AVT 7063 & 59.00 & 6.13 & 91.35 \\
\hline LSD (0.05) & NS & $\mathrm{NS}$ & $\mathrm{NS}$ \\
\hline CV (\%) & 14.03 & 13.14 & 6.79 \\
\hline Cropping systems & & & \\
\hline Intercropped & 62.48 & 6.18 & 93.30 \\
\hline Sole & 63.33 & 5.87 & 91.20 \\
\hline LSD (0.05) & NS & NS & NS \\
\hline $\mathrm{CV}(\%)$ & 13.47 & 12.00 & 6.06 \\
\hline
\end{tabular}

$\mathrm{NS}=$ not significant Means in a column followed by the same letters are not significantly different at $\mathrm{p} \leq 5 \%$ level of significance

\section{Numbers of harvest of tomato fruit}

The analysis of variance showed that population density had significant $(\mathrm{P} \leq 0.05)$ effect on numbers of harvesting; however no significant effect due to varieties, cropping system and interaction effects (Appendix Table 2).

The $50 \%$ population density gave significantly highest (3.91) number of harvest than the $75 \%$ and $25 \%$ there was no significance difference between the two population densities, $75 \%$ and $25 \%$ (Table 3 ). This might be the interspecies competition at $50 \%$ population density was as low as $75 \%$ population density and the interspecies competition as high as $25 \%$ population density. At lower population density the inter-specific competition was less this might be presence of no effective utilization of available resources finally gave less fruit yield and numbers of harvesting frequency, at $75 \%$ population density the competition was higher as compared to $50 \%$, and there might be scarcity of resources and shading effect. The present study was in line with Pal et al. (1993) revealed that the number of harvesting was increased with increasing population density, but it was up to certain population density and it starts to decline when population density increased beyond the available resources on a particular area. The absence of significant effect of varieties and cropping system indicates that any of the three varieties can be intercropped with tomato and intercropping does not affect number of harvest of tomato.

\section{Yield components and yields of tomato}

Number of fruit per cluster of tomato

Analysis of variance showed that population density had highly significant $(\mathrm{P} \leq 0.01)$ effect on number of fruit per cluster. However, unlike population density the varieties of African marigold, interaction and cropping system did not show significant effect (Appendix Table 3).

The highest (15.56) and lowest (8.23) number of fruit per cluster were recorded at $50 \%$ and $25 \%$ population density, respectively (Table 3). This might be the interspecies competition in intercropped African marigold at $50 \%$ population density was very positive. When the number of plants was less the inter species competition became low and non effective resources and space utilization might be exist. When population density increased from $50 \%$ to $75 \%$ the number of fruits per cluster reduced, this might be due to over plant population density on a given area. This result is supported by Ijoyah et al. (2015) who revealed that population density of okra significantly increased the number of egusi melon fruits per cluster, number of egusi melon seeds per fruit, weight of seeds per fruit and yield of egusi melon in okra-egusi melon intercropping. Planting of okra at the population density of 40,000 plants ha $^{-1}(50 \%)$ significantly increased yield of egusi melon, compared to when okra was sown at the population density of 50,000 (67\%) and 20,000 (25\%) plants ha ${ }^{-1}$. 
Table 3. Mean effects of population density, varieties and cropping system on Harvest duration, Number of harvest, number of per Fruit cluster and Number of Fruits per plant

\begin{tabular}{|c|c|c|c|c|}
\hline $\begin{array}{l}\text { Population } \\
\text { densities }\end{array}$ & $\begin{array}{l}\text { Harvest duration } \\
\text { (days) }\end{array}$ & $\begin{array}{l}\text { Number } \\
\text { of harvest }\end{array}$ & $\begin{array}{l}\text { Number of Fruit } \\
\text { per cluster }\end{array}$ & $\begin{array}{l}\text { Number of } \\
\text { fruits per plant }\end{array}$ \\
\hline $75 \%$ & $25.11 \mathrm{~b}$ & $3.33 b$ & $9.65 \mathrm{~b}$ & $38.63 b$ \\
\hline $50 \%$ & $29.56 \mathrm{a}$ & $3.91 \mathrm{a}$ & $15.56 \mathrm{a}$ & $45.89 \mathrm{a}$ \\
\hline $25 \%$ & $25.56 \mathrm{~b}$ & $3.28 b$ & $8.23 c$ & $32.38 \mathrm{c}$ \\
\hline LSD $(0.05)$ & 1.09 & 0.35 & 3.74 & 5.67 \\
\hline Varieties & & & & \\
\hline AVT 001 & $25.78 b$ & 3.47 & 11.94 & 37.60 \\
\hline AVT 540 & $27.56 \mathrm{a}$ & 3.53 & 14.03 & 41.06 \\
\hline AVT 7063 & $26.89 \mathrm{a}$ & 3.51 & 11.46 & 38.24 \\
\hline LSD (0.05) & 1.096 & NS & $\mathrm{NS}$ & NS \\
\hline CV $(\%)$ & 8.40 & 10.04 & 16.67 & 14.57 \\
\hline $\begin{array}{l}\text { Cropping systems } \\
\text { Intercropped }\end{array}$ & 26.74 & 3.50 & 11.81 & 38.97 \\
\hline Sole & 28.00 & 3.48 & 8.07 & 39.13 \\
\hline $\operatorname{LSD}(0.05)$ & NS & NS & $\mathrm{NS}$ & $\mathrm{NS}$ \\
\hline CV (\%) & 8.30 & 11.70 & 12.46 & 11.00 \\
\hline
\end{tabular}

\section{Number of fruit per plant}

Population density had highly significant $(\mathrm{P} \leq 0.001)$ effect on number of fruit per cluster. However, unlike population density the varieties of African marigold, interaction and cropping system did not show significant effect on number of fruit cluster per plant (Appendix Table 3). This is in agreement with the experimental result of Abd El-Gaid et al. (2014), revealed that number of fruits plant ${ }^{-1}$ may not significantly affected by tomatocommon bean intercropping.

The $50 \%$ and $25 \%$ population density produced significantly highest (45.89) and lowest (32.38) number of fruit per plant, respectively (Table 3). This might be due to the highest number of primary branches per plant is obtained due to $50 \%$ population density those branches forced to produce more number of fruits per plant when the net assimilation rate was higher. This is supported by the results of Ijoyah et al. (2015) that population density of okra significantly increased the number of egusi melon fruits per plant, number of egusi melon seeds per fruit, weight of seeds per fruit and yield of egusi melon in okra-egusi melon intercropping, Planting of okra at the population density of 40,000 plants ha ${ }^{-1}$ significantly increased yield of egusi melon, compared to when okra was sown at the population density of 50,000 plants ha ${ }^{-1}$. This result disagree with the findings of Tuan and Mao (2015) and Tesfaye (2008) who reported that fruit number per plant was significantly influenced by plant density but the low plant density resulting in significantly more fruit number as compared to high plant density.

Cropping system does not have significant effect on number of fruits per plant. These might be due to intercropping of African marigold protect tomato from different external factors like insect pests, frost and other environmental factors that results more number of fruit was produced. The reported results of Ijoyah et al. (2015) not supported this of which intercropping of okra with egusi melon increased the number of egusi melon fruits per plant, number of egusi melon seeds per fruit, weight of seeds per fruit and yield of egusi melon as compared to sole planting of egusi melon.

\section{Total fruit yield}

This study indicated that population density showed highly significant $(\mathrm{P}<0.01)$ effect on total fruit yield of tomato. However, there was no significant difference due to variety, interaction and cropping system on total fruit yield (Appendix Table 3).

The highest (13.8 ton $\mathrm{ha}^{-1}$ ) and lowest (10.80 ton ha $\mathrm{h}^{-1}$ ) total fruit yield was obtained from $50 \%$ and $25 \%$ population density, respectively (Table 4). This may due to almost all growth, yield related and yield of tomato were better at $50 \%$ population density as compared to others population density. There was no significant difference between $75 \%$ and $25 \%$ population density, at $75 \%$ interspecies competition might be higher and due to this the component crops exposed for shading effect, scarcity of available nutrients and soil moisture. Compound canopies of component crops that occur due to the presence high plant densities can maintain relative humidity within the canopy which is important in avoiding desiccation and makes good growth condition even during moisture deficit periods. Therefore intercropping composed of different patterns of canopy development and different maturation times can display a greater amount of leaf area over the course of the growing season and 
intercept more total light energy than less plant densities (monocultures). The reported result of Balasubramaniyan and Palaniappan (2001) showed that there is negative effect of very high population density particularly in branching crops due to competition for sun light under dense situation On the other had at $25 \%$ there might be loss of moisture, fertilizer, nutrient and light interception might be also less with associated to less interspesfic competition. Intercropping African marigold at $50 \%$ population density significantly increased tomato total fruit yield by $0.27 \%$ as compared to $25 \%$ population density of African marigold by $0.22 \%$. This result was supported by Yayock (1979) that showed fruit yield of tomato was increased as population density increased, but after certain point it starts to decline its yield because the increasing of interspesfic competition among the component crops (the demand crops for moisture, nutrient and solar ration might beyond the available resources on a given area) so it is better to know the optimum planting density among the component crops. This might be due to the risen of interspesfic competition among the component crops. Plant density significantly affected the interspecies dynamics of the component crops in intercropping (Rena et al., 2016 and Pal et al. 1993) as it is a major factor affecting the intercropping system of the component crops in terms of yield. This related to interspecies competition for soil moisture, nutrients, light and other common resources. This experiment showed that yields of component crops in the intercropping system vary significantly with the components population density. This result was disagreed with the reported results of Tesfaye (2008); Law-Ogbomo and Egharevba (2009) they reported that highest total fruit yield per hectare of tomato was obtained from low plant density than at high plant density (fruit yield of tomato was decreased with increased population density).

The cropping system showed no significant difference on fruit yield of tomato. This is in close agreement with Amin and Limbani (2007) that no significance difference was observed in cropping system of okra-cucumber intercropping. Though intercropping practices is done with the purpose of creating a system with higher combined yield that could benefit the farmers and enhance crop diversity as well as reduce total crop failure due to pest, disease. Intercropping of African marigold under tomato is better for farmers because they can be obtained a good fruit yield of tomato than planting alone. Because it protects tomato from different external environmental factors, it also activates and helps for efficient utilization of resources, it became more productive. The smaller yield loss of tomato under intercropping of African marigold could be due presence of African marigold.

Table 4. Mean effects of population density and varieties of African marigold intercropping on fruit weight, marketable fruit yield and unmarketable of tomato

\begin{tabular}{|c|c|c|c|}
\hline Population density & $\begin{array}{l}\text { Total fruit yield } \\
\left(\text { ton } \mathrm{ha}^{-1}\right)\end{array}$ & $\begin{array}{l}\text { Marketable fruit yield } \\
\left(\text { ton } \mathrm{ha}^{-1}\right)\end{array}$ & $\begin{array}{l}\text { Unmarketable } \\
\text { fruit yield (ton } \mathrm{ha}^{-1} \text { ) }\end{array}$ \\
\hline $75 \%$ & $11.75 \mathrm{~b}$ & $9.90 \mathrm{~b}$ & $1.85 \mathrm{~b}$ \\
\hline $50 \%$ & $13.80 \mathrm{a}$ & $13.11 \mathrm{a}$ & $0.69 \mathrm{c}$ \\
\hline $25 \%$ & $10.80 \mathrm{~b}$ & $7.56 \mathrm{c}$ & $3.24 \mathrm{a}$ \\
\hline LSD P (0.05) & 1.79 & 1.49 & 0.34 \\
\hline \multicolumn{4}{|l|}{ Varieties } \\
\hline AVT 001 & 11.41 & 10.39 & 1.02 \\
\hline AVT 540 & 12.00 & 10.33 & 1.67 \\
\hline AVT 7063 & 12.19 & 9.83 & 2.36 \\
\hline LSD P (0.05) & NS & NS & NS \\
\hline CV $(\%)$ & 7.38 & 11.18 & 10.51 \\
\hline \multicolumn{4}{|l|}{ Cropping system } \\
\hline Intercropped & 11.99 & $10.19 \mathrm{a}$ & $1.80 \mathrm{~b}$ \\
\hline Sole & 10.93 & $6.56 \mathrm{~b}$ & $4.37 \mathrm{a}$ \\
\hline LSD (0.05) & NS & 3.38 & 1.49 \\
\hline CV (\%) & 12.27 & 7.54 & 8.11 \\
\hline
\end{tabular}

LSD $(0.05)=$ least significance difference at probability level of 5\%, AVT=AV Tomas the name of the company, $\mathrm{NS}=$ non significance difference, Means in a column followed by the same letters are not significantly different at $\mathrm{p} \leq 5 \%$ level of significance; Where, $\mathrm{CV}=$ coefficient of variation,

\section{Marketable fruit yield}

The marketable fruit yield of tomato was highly $(\mathrm{P} \leq 0.001)$ affected by population densities and significantly by cropping system $(\mathrm{P} \leq 0.05)$ but not by African marigold varieties and interaction effect (Appendix Table 4). The $50 \%$ and $25 \%$ population density gave significantly the highest $\left(13.11\right.$ ton ha ${ }^{-1}$ ) and lowest 7.56 ton ha $^{-1}$ ) marketable fruit yield, respectively. The yield of tomato increased with African marigold population increased from $25 \%$ to $50 \%$ and then decreased to $75 \%$ of population densities (Table 4 ). This indicates that the $50 \%$ population density gave best marketable fruit yield than $25 \%$ and $75 \%$ population densities. This may due to almost all yields related parameter and yield of tomato were best and highest at 50\% population density as compared to other population densities of African marigold.

The highest marketable fruit yield of tomato was due to intercropping (10.19 ton $\left.\mathrm{ha}^{-1}\right)$ than sole cropping 
system (6.56 ton $\mathrm{ha}^{-1}$ ) (Table 4). This might be the presence and absence of African marigold in intercropped and sole cropping tomato. Because intercropping of African marigold serves as a trap crop and act as a physical barrier against different environmental factors and insect pest that attacks tomato fruits. It is supported by the experimental results of Hussain and Bilal (2007) reported the highest and lowest marketable fruit yield was observed in tomato-marigold intercropping and sole of tomato, respectively. The research of Wozniak and Wach (2011) is not similar with this experimental result in which intercropping carrot and parsley with marigold reduced the yield of both crops. The current study is also supported by (Koocheki et al., 2008 ; Gomez Rodriguez et al., 2003 ; Zavaleta-Mejía and Gomez, 1995) they reported that, intercropped tomato with African marigold, marigold plants serves as a physical barrier and promoted reductions in the maximum relative humidity surrounding the canopy, but to a lesser extent than marigold, it also altering the microclimatic conditions around the canopy, particularly by reducing the number of hours per day with relative humidity $>92 \%$, thus diminishing conidial development. The most common advantage of intercropping is to produce a higher yield from a given piece of land by achieving more efficient use of the available natural resources for crop growth that would otherwise not be utilized by each single crop grown alone (Lithourgidis et al., 2011). Therefore, in terms of land use efficiency intercropping is regarded as more productive than sole cropping (Andrews and Kassam, 1976). Higher nutrient uptake and better water use efficiency have also been present. Better use of solar radiation by intercrops was attributed to increased interception of photo synthetically active radiation resulting in higher radiation use efficiency.

\section{Unmarketable fruit yield}

Unmarketable fruit yield of tomato was highly $(\mathrm{P} \leq 0.01)$ affected by the population densities of African marigold and cropping system, but not by the varieties of African marigold and interaction effects (Appendix Table 4). The highest (3.24 ton ha-1) unmarketable fruit yield was obtained at $25 \%$ population density while the lowest $(0.69$ ton $\mathrm{ha}^{-1}$ ) was recorded from $50 \%$ population density (Table 4). The increased population density from $25 \%$ to $50 \%$, decreased the unmarketable fruit yield of tomato. This might be the ornamental nature of African marigold enables to prevent the yield loss of tomato fruit from extraneous factor like insect pests when intercropped it with $50 \%$ population density of African marigold.

In cropping system the highest ( 4.37 ton $\left.\mathrm{ha}^{-1}\right)$ and lowest $\left(1.80\right.$ ton $\left.^{-1} \mathrm{~h}^{-1}\right)$ unmarketable fruit yield was obtained from sole cropping and intercropping of tomato, respectively. This indicates that intercropping of marigold might have reduced the unmarketable fruit yield of tomato by serving as a trap crop for different pests that affect the marketable value of tomato. Improved productivity per unit incident radiation could be also achieved by the adoption of an intercropping system that either increase the interception of solar radiation and/or had greater radiation use efficiency. The findings of Francis (1986) and Ramakrishna and Ong (1994) they stated that the ability of intercrops to intensify resource use both in space and time dimension makes greater total use of available growth resources than mono cropping. Intercropping increased the amount of solar radiation intercepted due to faster canopy cover, which lead to efficient utilization of light resources. Keating and Carberry (1993) also stated that intercropping offers the advantage of efficient interception and utilization of solar radiation than mono cropping. This study agreed with that of Hussain and Bilal (2007) that the highest fruit damaged was from sole cropping of tomato as compared to tomato-marigold intercropping. Similar Jankowska et al. (2012) that the highest unmarketable yield of carrot was obtained from sole cropping but the lowest from carrot-marigold intercropping. Because intercropping of marigold with carrot enables to protect insect pests and other soil born nematodes by its flower and root system, respectively.

\section{Productivity of Tomato-African marigold Intercropping}

The productivity of intercropping was evaluated using the partial and total LERs as induces.

\section{Partial land equivalent ratio}

The analysis of variance showed that partial LER of tomato highly $(\mathrm{P} \leq 0.01)$ affected by population density, but varieties and interaction were not significantly affected (Appendix Table 7). The highest partial LER (0.84) of tomato was due to $50 \%$ population density, but no significant in between $75 \%$ and $25 \%$ population density (Table.7). Over all, partial LER of tomato increased as African marigold population density increased from $25 \%$ to $50 \%$ population density then decreased to $75 \%$ and $25 \%$ population density. This was probably the highest and lowest of inter-species competition due to $75 \%$ and $25 \%$ population density, respectively. Similarly Ijoyah et al. (2015) revealed that intercropping of okra with egusi melon land equivalent ratio was increased as population density of okra increased up to a certain point. The findings of Ram and Singh (2010) showed that the land equivalent ratio of tomato was significantly higher at $50 \%$ population density than $25 \%$ and $75 \%$ population densities in tomato -coriander intercropping. The reported result of Abidin et al. (1989) agree to the current study who reported that the highest LER value of tomato was obtained due to $50 \%$ population density than $75 \%$ and $100 \%$ in tomato-lettuce intercropping. 
The partial LER of African marigold was not significantly affected by population densities, the varieties and their interaction effects (Appendix Table 4). The intercropped tomato yielded the $61 \%$ to $69 \%$ and $54 \%$ to $84 \%$ of its sole crop yield in terms of African marigold varieties and population densities, respectively. This showed that intercropping was an advantageous as compared to sole cropping of either of the component crops as depicted by total LER values above one indicated complimentarily in resource utilization by the component crops. In addition, African marigold varieties yielded the $55 \%$ to $64 \%$ of their sole crop yield, while $55 \%$ to $61 \%$ of their sole crop yield was obtained due to African marigold population densities. This study is not similar with the finding of Modal et al. (2018) and Verma et al. (2011) that the partial land equivalent ratio of balsam and rose-scented geranium (Pelargonium geraviolence L.) were significantly affected by population density of cauliflower in cauliflower-balsam and geranium-cauliflower intercropping system respectively. Furthermore, the partial LER of tomato and African marigold were higher than 0.5 in all varieties and population density indicating that there was an advantage for both crops in these intercropping systems. But comparing the two partial LER values of the two combined crops, partial LER of tomato was higher than partial LER of African marigold in all cropping systems. Thus, the results ascertain that tomato were the major contributor to the mixture yield which also confirms the presence of greater competitive capacity of tomato against African marigold. This study was similar with Hailu et al. (2015) reported that the partial land equivalent ratio of tomato was higher than the partial land equivalent of maize in tomato/maize intercropping. Besides, tomato had a relatively larger upper canopy structures and the roots grow into larger area compared to African marigold.

\section{Total land equivalent ratio}

The analysis of variance showed that population density highly $(\mathrm{P} \leq 0.01)$ and variety and their interaction did not significantly affect LER (Appendix Table 4).

Total LER in all cases was more than unity (Table 5) indicating that intercropping of African marigold with tomato is advantageous than sole cropping of tomato. However, varieties and the interaction effect did not show significant variation on total LER (Appendix Table.4). Though varieties of African marigold were statistically no significant higher total LER (1.28) was obtained due to variety AVT 540 (Table 5). The highest total LER (1.43) was recorded when African marigold was planted at 50\% population density of its sole and the lowest LER (1.13) due to $75 \%$. There was no significant difference between $75 \%$ and $25 \%$ population density (Table 5 ). These values indicated that intercropping gave a $43 \%$ and $13 \%$ yield advantages than sole planting. These experiment was similar with result of Pareshbal and Patel (2016) reported that the highest total LER from 50\% population density of marigold (Jasmine + French marigold) followed by (Jasmine + African marigold). It is also supported by Gawade et al. (2003); Lakshminarayanan et al. (2005); Rahman et al. 2006 and Thankamani et al. (2011). The yield advantage could be due to a possible efficient utilization of growth resources by the intercropped crops or the intercropping advantages of weed reduction and increased light use efficiency (Willey, 1985). However, it is obvious that the optimum plant density could be achieved at certain points; to this effect optimum plant density was achieved at $50 \%$ of the sole population density of African marigold.

Table 5. Mean effects of population density, variety of African marigold and interaction effects on partial land equivalent ratio of tomato and African marigold, total land equivalent ratio and monetary advantage index of the component crops.

\begin{tabular}{|c|c|c|c|c|}
\hline $\begin{array}{l}\text { Population } \\
\text { densities }\end{array}$ & $\begin{array}{l}\text { Partial LER of } \\
\text { Tomato }\end{array}$ & $\begin{array}{l}\text { Partial LER } \\
\text { of African marigold }\end{array}$ & Total LER & $\begin{array}{l}\text { Monitory advantage index } \\
\left(\mathrm{ETB} \mathrm{ha}^{-1}\right)\end{array}$ \\
\hline $75 \%$ & $0.58 \mathrm{~b}$ & 0.55 & $1.13 \mathrm{~b}$ & $28,732 \mathrm{~b}$ \\
\hline $50 \%$ & $0.84 \mathrm{a}$ & 0.58 & $1.43 \mathrm{a}$ & $37,225 a$ \\
\hline $25 \%$ & $0.54 \mathrm{~b}$ & 0.52 & $1.15 \mathrm{~b}$ & $16,011 \mathrm{c}$ \\
\hline $\operatorname{LSD}(0.05)$ & 0.11 & NS & 0.15 & 8,140 \\
\hline \multicolumn{5}{|l|}{ Varieties } \\
\hline AVT 001 & 0.69 & 0.55 & 1.25 & 22,056 \\
\hline AVT 540 & 0.63 & 0.64 & 1.28 & 24,304 \\
\hline AVT 7063 & 0.61 & 0.52 & 1.19 & 17,608 \\
\hline LSD (0.05) & NS & NS & NS & NS \\
\hline CV $(\%)$ & 7.31 & 14.47 & 13.23 & 12.05 \\
\hline
\end{tabular}

Where, $\mathrm{MAI}=$ monitory advantage index, $\mathrm{LER}=$ land equivalent ratio, $\mathrm{AVT}=\mathrm{Av}$ Tomas (the name of the company), $\mathrm{CV}=$ coefficient of variation, $\mathrm{LSD}=$ least significance differences among treatments, NS= non significance difference.

\section{Monetary advantage index}

Monetary advantage index (MAI) was used to evaluate economic feasibility of intercropping in terms of increased value per unit area of land. The analysis of variance showed that the population density highly $(\mathrm{P} \leq 0.01)$ affected the MAI and had no significant effect by varieties of African marigold and interaction population density MAI 
(Appendix Table 5). However variety and interaction on the other hand did not show significant effect on MAI (Appendix Table 4). Monetary advantage of intercropping was indicated that there is no different between population density and varieties of African marigold.

The highest (ETB 37,225 $\mathrm{ha}^{-1}$ ) and lowest (ETB 16,011 ha- ${ }^{-1}$ ) MAI was obtained due to 50\% and $25 \%$ population density, respectively (Table 4 ). The $75 \%$ and $50 \%$ population density gave significantly the equally monetary advantage; this indicates that either of them can be used. Similarly, Kumar and Patra (2000) and Rao et al. (2000); Chellaiah et al. (2002); Verma et al. (2009) and Rao Rajeswara (2002) they reported that intercropping of vegetables with medicinal aromatic crops based cropping systems with their highest population density in north and south India has shown that farmers gain significantly higher profit from their lands.

\section{SUMMARY AND CONCLUSION}

Tomato is among the most important vegetable crops in Ethiopia. Its production in intercropping with African marigold in Ethiopia has not been reported as compared to other crops before in our country. Intercropping of African marigold within the row of tomato is the best way of introducing and increasing the production and productivity of African marigold in Ethiopia. Different researchers have indicated that planting marigolds between tomatoes protects the tomato plants from harmful root-knot nematodes in the soil, fruit borers and insect pests. African marigold cultivation has been became one of the priority aromatic medicinal crop under the program of aromatic and medicinal plants (AMPs) at Wondo Genet Agricultural Research Center (WGARC). Tomato and African marigold intercropping could increase income of smallholder farmers and promote production of African marigold at Wondo Genet area of Southern Ethiopia, through enhancing efficient utilization of land.

Field experiment was conducted at WGARC in 2017/18 cropping season, to assess effect of plant densities of intercropped African marigold varieties on yield related traits and yield of the associated crops and to evaluate the productivity and economic value of tomato and African marigold intercropping system.

The experiment consists of tomato variety "Melkashola", three African marigold varieties (AVT 001, AVT 540 and AVT 7063), three population densities of African marigold (25\%, 50\% and 75\%) and sole of the three African marigold varieties and tomato. Randomize complete block design in factorial arrangement with three replications was used.

Data collected for tomato were: on phenology and growth parameters of tomato, fruit cluster per plant, number of harvest, fruit yield, marketable fruit yield and unmarketable fruit yield of tomato. Plant height, days to $50 \%$ flowering, days to physiological maturity and days to first harvest of tomato were not significantly affected by varieties of African marigold, population densities, interaction. Variety AVT 540 significantly delayed (27.56 days) harvest duration of tomato to as compared to other varieties.

Population densities of African marigold significantly affected harvest duration (HD), numbers of harvest $(\mathrm{NH})$, number of fruit per cluster (NFPC), numbers of fruit per plant (NFPP), and total fruit yield (TFY), marketable fruit yield (MFY) and unmarketable fruit yield (UFY) of tomato. The $50 \%$ Population density delayed HD (29.56 days) as compared to other population densities. The highest (3.91) and lowest (3.28) NH were due to $50 \%$ and $25 \%$ population density respectively. Highest (45.89) and lowest (32.38) NFPP were obtained from 50\% and $25 \%$ population density respectively, and highest (15.56) and lowest (8.23) NFPC were also obtained from $50 \%$ and $25 \%$ population density of African marigold respectively. The highest TFY (13.80 ton ha- $\left.{ }^{-1}\right)$ and lowest ( 10.80 ton $^{-1} \mathrm{a}^{-1}$ ) of TFY, the highest (13.11 ton ha ${ }^{-1}$ ) and lowest (7.56 ton ha $\mathrm{a}^{-1}$ ) MFY were obtained from $50 \%$ and $25 \%$ population density of African marigold respectively, but the highest $\left(3.24\right.$ ton ha $\left.{ }^{-1}\right)$ and lowest $(0.69)$ UFY were obtained from $25 \%$ and $50 \%$ population densities respectively. Cropping system was showed non significant effect except marketable and unmarketable fruit yield of tomato, the highest $\left(10.19\right.$ ton ha $\left.{ }^{-1}\right)$ and lowest (6.56 ton $\left.\mathrm{ha}^{-1}\right)$ MFY and the lowest (1.67 ton $\mathrm{ha}^{-1}$ ) and highest (4.37 ton ha $\left.{ }^{-1}\right)$ of UFY were due to intercropped and sole of tomato respectively.

Varieties of African marigold had non-significant effect on partial land equivalent ratio (LER) of both tomato and African marigold, and total LER. Population density was non-significantly affected the partial LER of African marigold. The highest (0.84) partial LER of tomato and total LER (1.43) were recorded from 50\% population density. Intercropping of tomato with African marigold had a total LER value greater than 1 this showed the advantage of intercropping over sole cropping. Partial LER of tomato, total LER and monetary advantage index were significantly affected by population densities. The varieties were also non-significantly affected the monetary advantage index (MAI). The highest value of MAI (37,225 ton $\left.\mathrm{ha}^{-1}\right)$ was due to $50 \%$ population density. Intercropping of the two component crops at 50\% population density of African marigold gave LER values of 1.43 and MAI of 37,225 ETB ha ${ }^{-1}$. Therefore, African marigold with a density of 41,666.67 plants ha ${ }^{-1}$ and at a spacing of $48 \mathrm{~cm} \mathrm{x} 50 \mathrm{~cm}$ could be recommended for intercropping with tomato 45 days after tomato planting in the target area, based on its better compatibility, productivity and economic benefit.

Therefore, intercropping of African marigold varieties at $50 \%$ population density with tomato gave effective land utilization efficiency and more profitability. Since intercropping adds extra income and warrants insurance against a risk to the farmers, intercropping of tomato component was found to be advantageous than single 
cropping of tomato as there is a scarcity of land and a need to diversify production. Therefore, the inclusion of any of the three varieties of African marigold under tomato intercropping scheme raised yield advantage of intercropping over the single crop per year as revealed by the highest total LER and monetary advantage index.

Farmers can achieve greater benefit from their land by growing the main crop (Tomato) and in association with an increased plant population of the African marigold, which maintains at least $50 \%$ of the sole stand. Hence, Tomato/African marigold intercropping could increase incomes obtained by smallholder farmers at Wondo Genet area of Southern Ethiopia, through enhancing efficient utilization of land. Therefore, any of the three African marigold varieties at $50 \%$ population density could be recommended for intercropping with tomato

\section{ACKNOWLEDGMENTS}

First of all I would like to thank the Almighty God for giving strength and keeping me healthy to successes in my life. Foremost, I would like to express my sincere gratitude to Dr. Ketema Belete, for his consistent and incredible advice, valuable guidance and supervision and constructive criticisms starting from the beginning and completion of the study.

I extend my thanks to EIAR and WGARC for supporting, allowing field and laboratory facilities during this entire study. I would like to forward my appreciation to all laboratory technicians and field assistant (Mr. Abera Waritu) at WGARC for their technical support. I would also like to thank to my wife Tsedale Tesfaye for her frequent prayer, encouragement and support from the start of the experiment to this stage. Last but not the least; I have a great thanks to all my families and friends who encouraged me during the entire study period.

\section{REFERENCES}

Abayneh Esayas, Demeke Tafesse and Ashenafi Ali. (2006). Soils of Wondo Genet Agricultural Research Center, p. 67.Wondo Genet Agricultural Research Center, Wondo Genet.

Abbaszade, B., Farhadi, H. A., Valeabadi, A.S.A. and Moaveni, P. (20090). "Investigation of variations of the morphological values and flowering shoot yield in different mint species at Iran," Journal of Horticultural and Forestry, 1: 107-112.

Abd El-Gaid, M.A., Al-Dokeshy, M.H., Dalia, M.T. and Nassef, T. (2014). Effects of Intercropping System of Tomato and Common Bean on Growth, Yield Components and Land Equivalent Ratio in New Valley Governorate. Asian Journal of Crop Science, 6: 254-261.

Abidin, Z., Subban, R., and Basuki, R.S. (1989). Effect of intercropping of tomato with lettuce on growth, yield components and Land equivalent ration of the component crops in new valley Governorate, Australian Journal of Crop Science, 6(3) : 254-261.

Abraha Lemlem. (2013). On the effect of intercropping maize with cowpea and lablab on crop yield Herald, Journal of Agriculture and Food Science Research 2 (5):156 - 170.

Abera Habte, Mesfin Kassa and Adera Sisay. (2016). Maize (Zea mays L.) -Common Bean (Phaseolus vulgaris L.) Intercropping Response to Population Density of Component Crop in Wolaita Zone Southern Ethiopia. Journal of Natural Sciences Research .6:15.

Adeniyi, O.R., and Omotunde, C.T. (2001). Effect of Planting Pattern on Growth and Yield of Tomato-Cowpea Intercrops. Journal of Vegetable Crop Production, 7(2): 75- 81.

Andrews, D. J. and Kassam, A.H. 1976. The importance of multiple cropping in increasing world food supplies. In multiple cropping. American Society of Agronomy. 27: 1-10.

Anim, O.J. and LimbanI, N.V. (2007). Effect of Intercropping on the Growth and Yield of Cucumber (Cucumis sativus L.) and Okra (Abelmoschus esculentus L.) Moench. International Journal of Agriculture and Biology, 9(4): 594-597.

Balasubramaniyan, P. and Palaniappan, SP. (2001). Principles and Practices of Agronomy. Agrobios, Jodhpur (India). P 486-499.

Beemnet Mengesha Kassahun, Tigist German, Zewdinesh Damtew and Zinash Teferi. (2015). Evaluation of African marigold (Tagetes erecta L.) Varieties in Ethiopia EHSS $5^{\text {th }}$ Biennial Conference 14-15 February, 2015. Samara University.

Beemnet Mengesha. (2015). Overview of Herbs, Aromatic Plants and Essential Oils Research

Ethiopian Institute of, Friendship Hotel, Addis Ababa, Ethiopia.

Belstie Lulie1, Walelign Worku and Sheleme Beyene. (2016). Determinations of Haricot Bean (Phaseolus vulgaris L.) Planting Density and Spatial Arrangement for Staggered Intercropping with Maize (Zea mays L.) at Wondo Genet, Southern Ethiopia. Academic Research Journal of Agricultural Science and Research 4(6): 297-320.

Berimavandi, Hashemabadi, D., Vali, M., Ghaziani, F. and Kaviani, B. (2011). Effects of plant density and sowing date on the growth, flowering and quantity of essential oil of Calendula officinalis L. Rasht, Iran. Journal of Medicinal Plants Research 5(20):5110-5115.

Bilasvar, H.M. and Salmasi, S.Z. (2016). Essential oil yield and some morphological characteristics of sweet basil 
cultivars affected by different intercropping patterns with corn Department of Plant Ecophysiology, Faculty of Agriculture, University of Tabriz, Tabriz.Iran. Journal of Medicinal Plants Studies. 4(2): 09-12.

Caballero, R. and Goicoechea, E.L. (1995). Forage yield quality of common vetch and oat sown varing seeding ratios and seeding rates of vetch. Field Crops Research, 41: 135-140.

Chaerani, R. 2006. Early blight resistance in tomato: screening and genetic study. PhD Thesis, Wageningen University, Wageningen, Netherlands, Pp. 188.

Chellailah, N., Solaiappan, U. and Senthilevel, S. 2002: Effect of sowing time and intercropping on the yield of coriander under rainfed condiction,Madras Agricultural Journal, 88; 684 -689.

Choudhury, B. (1979). Vegetables $6^{\text {th }}$ Revised Edn. The Director, National Book Trust, New Delhi, India, P 46.

Cox, S. (2000). Colorado State; from discovery to modern commercialism: The complete story behind Lycopersicon escullentum.

CSA (Central Statistical Agency). (2018). Agricultural Sample Survey, 2017/18. Report on Area and Production for Major Crops (for Private Peasant Holdings 'Meher' season). Addis Ababa, Ethiopia.

Daniel Bisrat, Solomon Abate and Wossen Kebede. (2009). Laboratory Manual for plant products Analysis Volume I or Technical manual 23 (1).

Dawit Kassa and Afework Bekele. (2008). Species composition, abundance, distribution and habitat association of rodents of Wondo Genet, Ethiopia. SINET: Ethiopian Journal Science, 31(2):141-146.

Desalegn Regassa, Wakene Tigre and Addis Shiferaw. (2016). Tomato (Lycopersicon esculentum Mill.) varieties evaluation in Borana zone, Yabello district, southern Ethiopia. Journal of Plant Breeding and Crop Science, 8(10): 206-210.

Edossa Etissa, Nigussie Dechessa, Tena Alamirew, Yibekal Alemayehu and Lemma Desalegn.

(2013). Growth and yield components of tomato as influenced by Nitrogen and phosphorus fertilizer applications in different growing seasons. Ethiopian Journal of Agricultural Science, 23; 57-77.

Egbe, O.M. (2005). Evaluation of some agronomic potential of pigeon pea genotypes for intercropping with maize and sorghum in Southern Guinea Savanna. Ph.D. thesis, University of Agriculture, Makurdi, Nigeria. P. 134.

Egbe, O.M. (2010). Effects of plant density of intercropped soybean with tall sorghum on competitive ability of soybean and economic yield at Otobi, Benue State, Nigeria Journalof Cereals and Oilseeds, 1(1): $1-10$.

Eskandari, H. (2012). Yield and quality of forage produced in intercropping of maize (Zea mays) with cowpea (Vigna sinensis) and mungbean (Vigna radiate) as double cropped. Journal of Basic and Applied Scientific Research, 2: 93-97.

FAOSTAT (Food and Agricultural Organization of the United Nation Statistics). (2015). Over view the data set "Tomatoes, production quantity (tons)" for Ethiopia contains data from the year. Rome, Italy 1961- 2014.

Francis, C. A. (1986). Future perspectives of multiple cropping. pp. 351-370. In: C. A. Francis (eds.). Multiple Cropping Systems. Macmillan, New York.

Francis, C.A. (1989). Biological efficiencies in multiple cropping systems. Advance in Agronomy, 42: 1-42.

Gawade, M.H., Patil, J. D. and Kakade, D. S. (2003). Studies on effect of intercrops on yield and monetary returns of cauliflower. Agricultural Science and Digestion, 23(1): 73-74.

Geleta Lemma, Shimelis Ayele, Chimdo Abdi, Damtew Mengistu, Tiruwork Alemu. 1995. In: Proceedings of the 25th Anniversary of Nazareth Agricultural Research Center: 25 years of experiences in low land crops research, 20-23 September 1995.

Gomez, K, and Gomez, A.A. 1984. Statistical Procedures for Agricultural Research. 2nd edition. John Willey and Sons Ltd., New York, USA. P. 680.

Gomez-Rodriguez, O., Zavaleta-Mejía, E., González-Hernández, V.A., Livera-Mũnoz, M.E., and CárdenasSoriano, E. (2003). Allelopathy and microclimatic modification of intercropping with marigold on tomato early blight disease development. Field Crop Research, 83; 27-34.

Guenther E. (1972). The production of essential oils: Methods of distillation, effleurage, maceration and extraction with volatile solvents. Florida, USA: Kreieger Public Coorporation.Malabar.

Hadjiakhoondi A., Vatandoost, H., Khanavi M., Abaee M.R. and Karami M. (2005). Biochemical investigation of different extracts and larvicidal activity of Tagetes minuta L. on Anophelesstephensi Larvae. Iranian Journal of Pharmaceutical Research, 1:81-84.

Hailu Gebru, Kebede W/Tsadik, Tamado Tana. (2015). Effect of Planting Patterns in Tomato

(Lycopersicon esculentum Mill) and Maize (Zea mays L.) Intercropping on Growth, Yield and Yield Traits of the Crops in Wolaita Zone, Southern Ethiopia, Journal of Biology Agriculture and Healthcare, 1(5): 39-49.

Harnet Abrha, Abrha Kebede, Birhanu Amare, Mehari Desta. (2015). Effect of Inter and Intra- Row Spacing on Yield and Yield Components of Tomato (Solanum lycopersicum Linn.) in South Tigray, Ethiopia. Journal of Natural science Research, 5(5): 2224-3186.

Hussain, S.A. (2003). Growth, yield and economic impacts of intercropping in vegetables. A Dissertation Submitted to the NWFP Agricultural University, Peshawar. 5-14.

Hussain, B. and Bilal, S. (2007). Marigold as a Trap Crop Against Tomato Fruit Borer (Lepidoptera 
Noctuidae) .International Journal of Agricultural Research, 2: 185-188.

Ijoyah, M.O. (2012). Review of intercropping research: Studies on cereal-vegetable based cropping system and Science. Journal of Crop Science, 1(3):55-62.

Ijoyah, M.O., Alexander A., Fanen, F.T. (2016). Egusi Melon-Okra Intercrop: Yield Effects as Influenced by the Interaction of Time of Introducing Okra x Cropping Systems at Makurdi, Nigeria Agriculture and Biology Journal of Northern America 6; 1328-1332.

Ijoyah, M.O., Fanen, F.T.,Aindigh, F.D. (2015). Optimum Plant Density of Okra and Intercropping Effects on Yields of Egusi melon-Okra Mixture, at Makurdi, Nigeria Agriculture and Biology Journal of Northern America 38 : 46-55.

Jankowska, B., Jędrszczyk, E. and Małgorzata Poniedziałek, M. (2012). Effect of intercropping carrot (daucus carota 1.) with French marigold (Tagetes patula nana l.) and pot marigold (Calendula officinalis L.) on the occurrence of some pests and quality of carrot yield, ACTA AGROBOTANICA 65 (4): 133-138.

Karimzadeh P., Salmasi S.Z, Kalvanagh S.I, Janmohammadi H. (2015). Essential oil production of dill affected by different intercropping patterns with berseem clover and harvesting times,University of Tabriz, Iran.International Journal of Biosciences, 6(3): 1-6.

Katzer, G, Modification. (2004). Peppermint (Mentha piperita L.). [Online]. Available: http://www.unigraz.at/ katzer/engl/Ment pip.html .Accessed (date June 12, 2018).

Keating, B.A. and Carberry, P.S. (1993). Resource capture and use in intercropping. Solar radiation. Soil, 141:119135.

Khorshidi, J., Tabatabaei, M.F., Omidbaigi, R. and Sefidkon, F. (2009). The Effect of Different Densities of Planting on Morphological Characters, Yield, and Yield Components of Fennel (Foeniculum Vulgare Mill cv. Soroksary) Department of Horticulture Science, University of Tehran, Karaj, Iran Journal of Agricultural Science. 1(2): 66-73.

Koocheki, A., Alimoradi,L., Azizi, G. (2008). Allelopathic Effect of Intercropping with Marigold and Common Rosemary on Tomato Early Blight Disease Development Ferdowsi University of Mashhad, Department of Agronomy, Iran.

Kumar, S. and Patra, D.D. (2000). Integinal Paration of Mediculture with Agriculture for sustainable higher productivity, profits and employment. Journal of Aromatic and Medicinal PlantScience, 22: 751-754.

Lakshminarayanan, M.; Haripriya, K., Manivannan, K., and Kamalakannan, S. (2005). Evaluation of leguminous vegetables as intercrops in pruned fields of jasmine (Jasminum sambac) Journal of Spices and Aromatic Crops, 14(1): 61 -64.

Law-Ogbomo, K.E., Egharevba, R.K.A. (2009). Effects of planting density and npk fertilizer application on yield and yield components of tomato (Lycospersicon esculentum Mill) in forest location. World Journal of Agricultural Sciences. 5(2):152-158.

Lemma Desalegn, Yayeh Zenebe. and Helath. E. (2003). Agronomic studies on Tomato and Capsicum. Pp.153.In: Helath E. and Lemma D, $(E d s)$. Horticultural Research and Development in Ethiopia. Proceedings of the Second Horticultural work shop of Ethiopia, 1-3 December, 1992. Addis Abeba, Ethiopia.

Lithourgidis, A.S., Dordas, C.A., Damalas, C.A. and Vlachostergios, D.N. (2011). Review article Annual intercrops: an alternative pathway for sustainable agriculture, Australian Journal of Crop Science, 5(4):396410.

Mansoori, I. (2014). "The Effect of Plant Density and Harvesting Time on Growth and Essential Oil of Peppermint (Mentha Piperita L.),".Iranian, Journal of Medical and Bioengineering. 2(3): 113-116.

Martin, M.P.L.D. and Snaydon, R.W. (1982). Intercropping barley and beans I. Effects of planting pattern. Experimental Agriculture, 18: 139-148.

Mazaheri, D., Madani, A. and Oveysi, M. (2006). Assessing the land equivalent ratio (LER) of two corn (Zea mays L.) varieties intercropping at various nitrogen levels in Karaj, Iran. Journalof Central European Agriculture, 7(2): 359-364.

Mead,R. and Willey, R.W. (1980). The concept of a 'land equivalent ratio' and advantages in yields from intercropping. Experimental Agriculture, 16:217-228.

Miguel, M. G., Duarte, F., Venancio, F., and Tavares, R. (2004). "Composition of the essential oils from ortuguese Thymus albicans collected at different regions of Ria formasa (Algarve)," Journa of Essential oil Research, 1: 308-311.

Mimica-Dukic, N., Bozin, B., Sokovic, M., Mihailovic, B. and Matavulj, M. (2003). "Antimicrobial and antioxidant activities of three Menthaspecies essential oils," Planta Medica, 69: 413-419.

Mondal, S., Sarkar, M.M., Ghosh, T., Kumar, T. and Mai, K.T. (2018). Effect of Mono cropping and Intercropping of Vegetable- Flower Components on Production, Economics and Land Use Efficiency under Sub-Tropical Zone of West Bengal, India.Current Journal of Applied Science and Technology 26(6): 1-7.

Mulugeta Tsedalu, Bizuayehu Tesfaye and Yasin Goa. (2014). Effect of Type of Planting Material and Population Density on Corm Yield and Yield Components of Taro (Colocasia Esculenta L.) Gambella Peoples National 
Regional State Agricultural Bearu, Ethiopia, Journal of Biology, Agriculture and Healthcare. 4: 17.

NHB (National Horticulture Board). (2014). Anon ymous. Statistical data, Ministry of Agriculture, Govt. of India (2013-14).

Pal, V., Oseni, T. and Norman, J. (1993). Effects of component densities on the productivity of soybean/maize and soybean/sorghum intercrop. Journal of Agronomy, 170: 66-70.

Pareshbhai, D.T. and Patel, G. D. (2016). Intercropping of annual flowers in Jasminum sambac L. A thesis submitted to the Navsari Agricultural University Navsari Department of Floriculture and Landscape architecture Aspee College of Horticulture and Forestry Navsari Agricultural University Navsari, Gujarat State.

Rahman, M. Z., Rahman, H. H.; Haque, M. E.; Kabir, M. H.; Naher, S. L.; Ferdaus, K. M. K. B.; Nazmul Huda, A. K. M.; Imran, M. S. and Khalekuzzaman, M. (2006). Banana based intercropping system in North-West part of Bangladesh. Journal of Agronomy, 5(2): 228-231.

Ramakrishna, A. and Ong, C.K. (1994). Productivity and light interception in upland rice /legume intercropping systems. Tropical Agriculture, 71 (1): 5-11.

Ram, M., Ram, D. S., Sing, S., Roy, K. and Kumar, S. (2001). "Effect of planting time on the growth and essential oil yield in different varieties of menthol mint (Mentha arvensis L.)," International Journal of Medicinal and Aromatic Plant Science, 22: 400-403.

Ram, S. and Singh, S. (2010). Effect of intercropping of spices, cereal and root crops on the incidence of helicoverpa armigera (hub.) in tomato. Journal vegetable Science. 37(2): 164-166.

Rao, M.R., Palada, M.C., Becker, B.N. (2004). Medicinal and aromatic plants in agroforestry systems. Agroforestery System 61: 107-122.

Rao, R., B.R. 2002. Rose-scented geranium (pelargonium sp.) Indian and international prospective. Journal of medicinal and aromatic plant science, 22: 302 - 311.

Rao, E.V.S.P., Puttanna, K., Rao, R.S.G., Kumar, S. (2000). Prospect of commercial mediculture and recent advances in agrotechnologies of aromatic plants in South India. Journal of Medicinal Aromatic and Plant Science 22 (1B); 207-213.

Sadeghi M.N, Mirshekari, B., Kouchebagh, S.B., Al, S. (2013). Time of bean sowing time related to marigold in different intercropping systems could be increase their yields Department of Agronomy and Plant Breeding, Tabriz Branch, Islamic Azad University, Tabriz, Iran, Life Science Journal 10:151-155.

Setotaw Feleke. (2006). Impacts of technological change on household production and food security in smallholder agriculture. The case of wheat-Tef based farming systems in the central highlands of Ethiopia, Central highlands of Ethiopia Setotaw Feleke.

Singh, P., Krishna A., Kumar V., Krishna S., Singh K., Gupta M. (2016). Chemistry and biology of industrial crop Tagetes Species: A review Journal of Essential Oil Research. 28:1-14.

Singh, D.C., Kumar, S.A., Kiran, V. 2015. Intercropping of medicinal plants International Journal of Applied Ayurved Research, 2347- 6362.

Singh, A, Khanuja, S.P.S, Arya, J.K, Singh A., Yadav, A. (2006). Essential oil quality and yield with respect to harvest index in Tagetes minuta cultivated in sub-tropical plains of north India Journal of Essential Oil Research; 18: 362-365.

Tesfaye Balemi. (2008). Response of tomato cultivars differing in growth habit to nitrogen and phosphorus fertilizers and spacing on vertisol in Ethiopia. Acta Agriculturae Slovenica. 91(1):103-119.

Tewodros Mulualem, Asfaw Kefelegn. (2013). Promotion and evaluation of improved technologies through participatory approach in South Ethiopia: Experience from hot pepper. UniqueResearch Journal of Agricultural Science, 1(4):57-62.

Thankamani, C. K., Kandiannan, K., Madan, M. S., and Raju, V. K. (2011). Crop diversification in black pepper gardens with tuber and fodder crops. Journal plantation. Crops, 39 (3): 358-362.

Tuan, N.M., and Mao, N.T. (2015). Effect of Plant Density on Growth and Yield of Tomato (Solanum lycopersicum L.) at Thai Nguyen, Vietnam, International Journal of Plant and Soil Science 7(6): 357-361.

Valdez, F.R. and Fransen, S.C. (1986). Corn-Sunflower intercropping as silage crop. Journal of

Dairy Science, 69: 138-142.

Vandermeer, J.H. (1992). The Ecology of Intercropping Publisher: Cambridge University Press.

Verma, R.K., Rahman, R., Verma, A., Yadav, sunita mishra A., Chauhan, A., Sing, A., kalra, A.K. Kukreja and S.P.S. khanuja. (2009). Biomass yield, essential oil yield and resource use efficiency of peppermint (minta piperta L) intercropping with geranium. (Pelargoniumgeraviolence L.) Under different plant density crop production. Journal of Environmental Biology, 44: 577-582.

Willey, R.W. (1979). Intercropping- its importance and research needs. Part 1: Competition and yield advantages. Field Crop Research, 32: 1-10.

Willey, R.W. (1985). Effect of row arrangement on light interception and yield in sorghum-pigeopea intercropping Journal of Agricultural Science 10(4): 122-126. 
Willey, R.W. (1990). Resource use in intercropping systems. Journal of Agriculture and Water

Management, 17: 215-231.

Willey, R.W. and Osiru, D.S.O. (1972). Studies on the mixtures of maize and beans with particular reference to plant population. Journal Agricultural Science, 79: 517-529.

Woiniak, M.B. and Wach, D. (2011). The effect of intercropping on yielding of root vegetables of Apiaceae Family, University of Life Sciences in Lublin, Acta Science Political Hortum Cultus, 10(4) :233-243.

Yayock, J.Y. (1979). Crops and cropping patterns of the savanna region of Nigeria the Kaduna situation. Proceedings of the international workshop on intercropping, Hyderabad, India, 10-13th January

Zavaleta-Mejía, E., Gómez, R.O. (1995). Effect of Tagetes erecta L. and Tomato (Lycopersicon esculentum Mill). Intercropping on some tomato pests. Fitopatologia , 30; 33-45.

Zhang, F. and Li, L. (2003). Using competitive and facilitative interactions in intercropping systems enhances crop productivity and nutrient-use efficiency. Plant and Soil,1: 248-254.

Zulu-Natal, K. (2001). Department of Agriculture and Environmental Affairs. Vegetable production guidelines for Kwazulu-Natal. Pietermaritzburg, 305-312.

\section{APPENDICES}

Appendix Table 1. Mean square values of ANOVA for Phenology and growth parameter as affected by population density, varieties and cropping system

\begin{tabular}{|c|c|c|c|c|c|}
\hline $\begin{array}{l}\text { Sources of } \\
\text { variation }\end{array}$ & $\mathrm{DF}$ & Plant height & $\begin{array}{l}\text { Number of primary } \\
\text { branches }\end{array}$ & $\begin{array}{l}\text { Days to } 50 \% \\
\text { flowering }\end{array}$ & $\begin{array}{l}\text { Days to physiological } \\
\text { matutiy }\end{array}$ \\
\hline Rep & 2 & 12.48 & 0.06 & 70.78 & 169.44 \\
\hline VAR & 2 & $126.259 \mathrm{~ns}$ & $0.0123 \mathrm{~ns}$ & $33.33 \mathrm{~ns}$ & $69.44 \mathrm{~ns}$ \\
\hline PD & 2 & $43.81 \mathrm{~ns}$ & $13.141 * * *$ & $10.33 \mathrm{~ns}$ & $175.00 \mathrm{~ns}$ \\
\hline PD*VAR & 4 & $67.81 \mathrm{~ns}$ & $0.403 \mathrm{~ns}$ & $22.67 \mathrm{~ns}$ & $177.78 \mathrm{~ns}$ \\
\hline Error & 16 & 76.90 & 0.66 & $38.69 \mathrm{~ns}$ & $129.86 \mathrm{~ns}$ \\
\hline $\mathrm{CV}(\%)$ & & 14.03 & 13.14 & 12.67 & 12.98 \\
\hline Rep & 2 & $22.53 \mathrm{~ns}$ & $0.27 \mathrm{~ns}$ & $55.23 \mathrm{~ns}$ & $130.33 \mathrm{~ns}$ \\
\hline $\mathrm{CS}$ & 1 & $63.56 \mathrm{~ns}$ & $0.90 \mathrm{~ns}$ & 116.03 & $213.33 \mathrm{~ns}$ \\
\hline Error & 2 & 71.94 & 0.42 & 33.11 & 131.60 \\
\hline CV $(\%)$ & & 13.47 & 12.00 & 11.56 & 12.94 \\
\hline
\end{tabular}

$*, * *, * * *$ significant at $\mathrm{P} \leq 0.05, \mathrm{p} \leq 0.01$ and $\mathrm{p} \leq 0.001$ probability levels respectively; $\mathrm{ns}=$ not significant difference; $\mathrm{Rep}=$ replication; $\mathrm{VAR}=$ variety; $\mathrm{PD}=$ population density; $\mathrm{CS}=$ cropping system; $\mathrm{CV}=$ coefficient of variation; $\mathrm{SOV}=$ Source of variations; $\mathrm{DF}=$ degree of freedom.

Appendix Table 2. Mean square values of ANOVA for days to first harvest, Number of harvest and Harvest duration as affected by population density, varieties and cropping system

\begin{tabular}{lllll}
\hline SOV & DF & Days to first harvest & Number of harvest & Harvest duration \\
\hline Rep & 2 & 152.29 & 0.11 & 1.037 \\
VAR & 2 & $38.339 \mathrm{~ns}$ & $0.0133 \mathrm{~ns}$ & $7.259^{*}$ \\
PD & 2 & $27.064 \mathrm{~ns}$ & $1.0844^{*}$ & $53.93^{* *}$ \\
PD*VAR & 4 & $8.593 \mathrm{~ns}$ & $0.1244 \mathrm{~ns}$ & $2.37 \mathrm{~ns}$ \\
Error & 16 & 40.182 & 0.1244 & 5.35 \\
\hline CV $(\%)$ & & 6.79 & 10.04 & 8.40 \\
\hline Rep & 2 & $142.085 \mathrm{~ns}$ & $0.028 \mathrm{~ns}$ & $2.53 \mathrm{~ns}$ \\
CS & 1 & $11.95 \mathrm{~ns}$ & $2.225 \mathrm{~ns}$ & $0.73 \mathrm{~ns}$ \\
Error & 2 & 31.90 & 0.18 & 5.22 \\
\hline CV $(\%)$ & & 6.06 & 11.70 & 8.30 \\
\hline
\end{tabular}


Appendix Table 3. Mean square values of ANOVA for number of per fruit cluster, number of fruit per plant, fruit weight ton per hectare by population density, varieties and cropping system on tomato

\begin{tabular}{|c|c|c|c|c|}
\hline $\begin{array}{l}\text { Source of } \\
\text { variation }\end{array}$ & $\begin{array}{l}\text { Degree of } \\
\text { freedom }\end{array}$ & $\begin{array}{lr}\text { Number } & \text { of } \\
\text { Fruit } \\
\text { cluster }\end{array}$ & $\begin{array}{l}\text { Number of fruit } \\
\text { per plant }\end{array}$ & Fruit weight ton per hectare \\
\hline Rep & 2 & 18.98 & 124.448 & 2.574 \\
\hline VAR & 2 & $16.69 \mathrm{~ns}$ & $30.388 \mathrm{~ns}$ & $1.48 \mathrm{~ns}$ \\
\hline $\mathrm{PD}$ & 2 & $453.38 * * *$ & $411.488 * *$ & $25.32 * *$ \\
\hline PD*VAR & 4 & $24.814 \mathrm{~ns}$ & $85.342 \mathrm{~ns}$ & $2.55 \mathrm{~ns}$ \\
\hline Error & 16 & 14.04 & 12.21 & 3.24 \\
\hline CV (\%) & & 16.67 & 14.57 & 10.16 \\
\hline Rep & 2 & $16.208 \mathrm{~ns}$ & 64.83 & 0.97 \\
\hline $\mathrm{CS}$ & 1 & $51.00 \mathrm{~ns}$ & $204.02 \mathrm{~ns}$ & $2.35 \mathrm{~ns}$ \\
\hline Error & 2 & 16.63 & 66.54 & 4.87 \\
\hline $\mathrm{CV}(\%)$ & & 12.46 & 11.00 & 8.74 \\
\hline
\end{tabular}

Appendix Table 4. Mean square values of ANOVA on Marketable fruit yield and Unmarketable fruit yield by population density, varieties and cropping system on tomato

\begin{tabular}{llll} 
SOV & Degree of freedom & Marketable fruit yield & Unmarketable fruit yield \\
\hline Rep & 2 & 3.00 & 0.016 \\
VAR & 2 & $0.84 \mathrm{~ns}$ & $0.1085 \mathrm{~ns}$ \\
PD & 2 & $69.93^{* * *}$ & $16.86^{* * *}$ \\
PD VAR & 4 & $360.99 \mathrm{~ns}$ & $0.076 \mathrm{~ns}$ \\
Error & 16 & 2.25 & 0.118 \\
\hline CV $(\%)$ & & 11.18 & 10.51 \\
\hline Rep & 2 & $1.71 \mathrm{~ns}$ & $11.90 \mathrm{~ns}$ \\
CS & 1 & $35.59^{*}$ & $105.76^{* * *}$ \\
Error & 2 & 7.32 & 1.428 \\
\hline CV $(\%)$ & & 7.54 & 8.11 \\
\hline
\end{tabular}

$*, * *, * * *$ significant at $\mathrm{P} \leq 0.05, \mathrm{p} \leq 0.01$ and $\mathrm{p} \leq 0.001$ probability levels respectively; $\mathrm{ns}=$ not significant difference; $\mathrm{Rep}=$ replication; $\mathrm{VAR}=$ variety; $\mathrm{PD}=$ population density; $\mathrm{CS}=$ cropping system; $\mathrm{CV}=$ coefficient of variation; $\mathrm{SOV}=$ Source of variations; $\mathrm{DF}=$ degree of freedom. 